\title{
Clinical investigation of chromosomal karyotype analysis in cells cultured from fetal bladder puncture liquid
}

\author{
JIAN GAO \\ Center for Reproduction and Genetics, Hebei General Hospital, Shijiazhuang, Hebei 050051, P.R. China
}

Received August 25, 2015; Accepted October 21, 2016

DOI: $10.3892 / \mathrm{etm} .2017 .4744$

\begin{abstract}
The aim of this study was to investigate the feasibility of performing chromosomal karyotype analysis using cells cultured from fetal bladder puncture liquid (FBPL). Therefore, FBPL was extracted from 9 fetuses under ultrasonographic guidance, including 3 cases with fetal lower urinary tract obstruction (megabladder and oligohydramnios) and 6 cases with multiple malformations. The cells obtained from the FBPL were cultured in vitro for chromosome preparation and karyotype analysis. The cells from these 9 cases were all successfully cultured, and the chromosomal mitotic phases obtained could be used for counting and karyotype analysis. The gestational age ranged from 14 weeks and 2 days to 22 weeks, the amount of FBPL extracted was 30-55 ml, and the cell culture time ranged from 14 to 21 days. Eight cases in which the cells were subcultured exhibited 22-30 chromosomal mitotic phases, whereas 1 case without subculture showed 11 chromosomal mitotic phases. Cells obtained from the FBPL were successfully used for karyotype analysis following in vitro culture, thus demonstrating that prenatal fetal chromosome examination is possible in patients with a low gestational age, megabladder and oligohydramnios. These observations indicate that this technique has the potential to be used as a new prenatal diagnostic method.
\end{abstract}

\section{Introduction}

At present, the cells that can be examined by clinical karyotype analysis include peripheral blood lymphocytes, amniotic fluid cells, placental villus cells, fetal blood cells, bone marrow cells, pleural effusion cells and solid tumor cells (1-7), among which amniotic fluid cells, placental villus cells and umbilical cord blood cells are the main cells used for prenatal diagnosis.

Correspondence to: Professor Jian Gao, Center for Reproduction and Genetics, Hebei General Hospital, 348 Heping West Road, Shijiazhuang, Hebei 050051, P.R. China

E-mail: jiangaocn@163.com

Key words: prenatal diagnosis, bladder puncture fluid, cell culture, karyotype analysis
As prenatal ultrasound diagnosis technologies improve, it is possible to find many fetal abnormalities at an earlier stage.

Fetal bladder outlet obstruction is a severe fetal abnormality, with an incidence rate of $\sim 2.2 / 10,000$ newborns; the associated mortality rate may be as high as $45 \%$ (8). Due to the presence of typical morphological abnormalities such as megabladder and oligohydramnios in these cases, the condition can be diagnosed by ultrasonography in early pregnancy (9). Genetic diagnosis in pregnant women carrying a fetus with this abnormality at a gestational age of 14-16 weeks is often difficult, as amniotic fluid is lacking and, therefore, fetal amniotic fluid cells cannot be obtained through amniocentesis; hence, the optimal time for umbilical vein puncture is after 20 weeks of gestation (10). It has been shown that in cases with a short gestational age (particularly in the first 16 weeks of pregnancy), the umbilical vein diameter was $<3 \mathrm{~mm}$, and therefore, it is difficult to determine the depth and accuracy of needling (11). In such cases, the needle might slip, and result in a high puncture failure rate. Furthermore, in cases with a low gestational age, the fetal blood volume is low, and the tolerance of the umbilical vein puncture is poor; this could increase the risks of complications, such as fetal bradycardia (12). The optimal time for fetal chorionic puncture $<14$ weeks after pregnancy; after this time, the villus branches become thicker, and therefore, cell culture would be difficult (13).

Therefore, in the present study, the aim was to investigate the results for 9 cases in which cell culture and karyotype analysis was conducted using samples of fetal bladder puncture liquid (FBPL).

\section{Materials and methods}

Subjects. From December 2010 to October 2014, cells from the FBPL of 9 cases were cultured; 3 cases required further prenatal diagnosis as they were initially diagnosed with lower urinary tract obstruction (fetal megabladder, oligohydramnios) on ultrasonography (Figs. 1 and 2), whereas 6 cases required prenatal diagnosis because of multiple fetal malformations (Table I). The ages of the pregnant women ranged from 23 to 34 years, with gestational ages ranging from 14 weeks and 2 days to 22 weeks. FBPL was obtained during the filling stage of the bladder. The study was approved by the Medical Ethics Committee of Hebei General Hospital (Shijiazhuang, China), and study subjects signed an informed consent form. Cases 1 and 2 had a history of fetal growth arrest in an earlier pregnancy. 
Fetal bladder puncture (FBP). Following routine preoperative preparations, FBP was performed under ultrasonographic guidance (Aloka SSD 5500 color Doppler; Hitachi Aloka Medical, Ltd., Tokyo, Japan; with a $3.5 \mathrm{MHz}$ linear special puncture probe). The amounts of FBPL obtained from the 3 cases with lower urinary tract obstruction were $55 \mathrm{ml}$ (case 1), $30 \mathrm{ml}$ (case 2), and $35 \mathrm{ml}$ (case 3), whereas those obtained from the 6 cases with multiple malformations ranged from 30 to $35 \mathrm{ml}$.

Cell culture and chromosomal preparation with FBPL. The FBPL was centrifuged ( $800 \mathrm{x} \mathrm{g} ; 8 \mathrm{~min})$ using conventional methods at room temperature. The precipitate obtained after centrifugation under sterile conditions $(0.5-1 \mathrm{ml})$ was then seeded into two culture flasks, and $4 \mathrm{ml}$ Chang Medium Amnio $^{\mathrm{TM}}$ (Irvine Scientific, Santa Ana, CA, USA) was added; the cells were gently pipetted into a cell suspension, and then cultured at $37^{\circ} \mathrm{C}$ with $5 \% \mathrm{CO}_{2}$. The cells were removed from the incubator 1 week after the culture was initiated, and were observed under an inverted microscope. Some cells adhered to the flask wall, but a few small colonies were also noted. Eight of these cases underwent subculturing. When appropriate cell density was observed under the microscope, as determined by the bottom of the culture bottle being covered with cells, and the cells were round, bright and protruding from the bottom of the culture bottle, they were harvested for conventional slide preparation, G-band development, and the counting and analysis of chromosomal karyotypes (14).

\section{Results}

FBPL sampling, culture and examination. The FBPL amount, incubation time, passage conditions and number of mitotic phases obtained are shown in Table I.

FBPL sampling. FBP was performed successfully at the first attempt in each case, and the amount of FBPL extracted for culture ranged from 30 to $55 \mathrm{ml}$ (mean, $35 \mathrm{ml}$ ). No active bleeding was observed and no hematoma formed at the fetal abdominal puncture site.

Culture of the FBPL samples. The 9 specimens were all successfully cultured. Cell numbers in the FBPL were observed to be less than those in the same amount of amniotic fluid. Cells were observed as single cells, with a polygonal or nearly round appearance. Following culture, the cells appeared spindle-shaped or star-like (Fig. 3). Among the 9 cases, 8 cases underwent subculturing. The culture time ranged from 14 to 21 days (mean, 16 days).

Mitotic phases. Eight cases that underwent subculturing showed 22 to 30 mitotic phases, whereas the 1 case that did not undergo subculturing showed 11 mitotic phases (Fig. 4). The chromosomal images were clear, and the karyotype description was based of the International System for Human Cytogenomic Nomenclature (ISCN) 2005 (5).

\section{Discussion}

In 1966, Steele and Breg successfully isolated fetal exfoliated cells from amniotic fluid and cultured them in vitro (1).

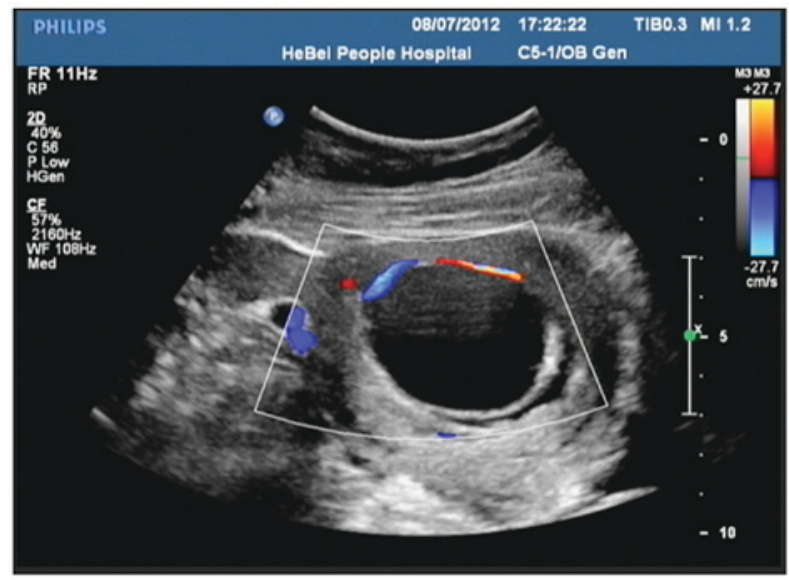

Figure 1. Case 2 ultrasound image: The fetal bladder was enlarged, with the signal of umbilical artery blood flow only visible in one side of the bladder.

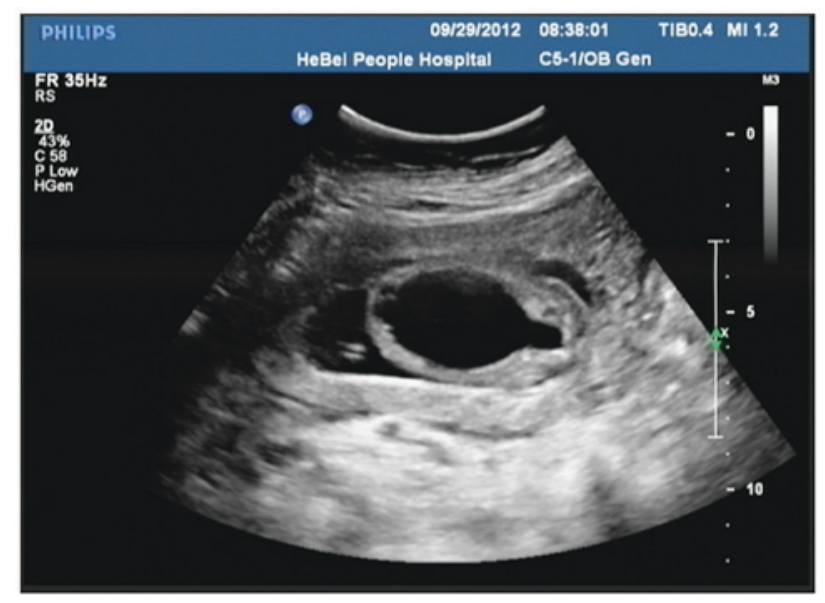

Figure 2. Case 3 ultrasound images: 'Keyhole sign' of enlarged fetal bladder and post-bladder neck urethral meatus.

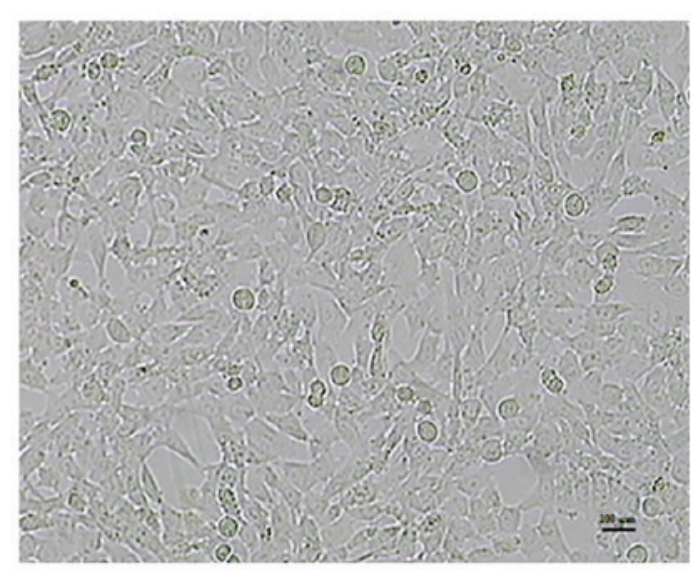

Figure 3. Cells in bladder fluid after culture (magnification, x100). Scale bar, $100 \mu \mathrm{m}$.

The chromosomes of the cultured cells were also analyzed and, thus, the prenatal diagnosis of chromosomal disorders became possible. At present, fetal cell culture and karyotype analysis remain the classical detection methods for fetal chromosomal abnormalities $(15,16)$. Culture and karyotype analysis 
Table I. Culture conditions of cells from fetal bladder puncture liquid in 9 cases.

\begin{tabular}{|c|c|c|c|c|c|c|c|}
\hline Case no & $\begin{array}{c}\text { Age } \\
\text { (years) }\end{array}$ & $\begin{array}{l}\text { Gestation } \\
{(\text { weeks })^{\mathrm{a}}}^{\text {wo }}\end{array}$ & $\begin{array}{c}\text { Reason for } \\
\text { prenatal diagnosis }\end{array}$ & $\begin{array}{c}\text { Liquid } \\
\text { amount in } \\
\text { bladder }(\mathrm{ml})\end{array}$ & $\begin{array}{c}\text { Longest } \\
\text { culture } \\
\text { time (days) }\end{array}$ & $\begin{array}{c}\text { Subculture } \\
\text { or not }\end{array}$ & $\begin{array}{c}\text { Chromosomal } \\
\text { mitotic } \\
\text { phases }(\mathrm{n})\end{array}$ \\
\hline 1 & 34 & $15^{+1}$ & Lower urethral obstruction & 55 & 21 & Yes & 30 \\
\hline 2 (Fig. 1) & 28 & $14^{+2}$ & Lower urethral obstruction & 30 & 15 & No & 11 \\
\hline 3 (Fig. 2) & 32 & $19^{+1}$ & Lower urethral obstruction & 35 & 14 & Yes & 22 \\
\hline 4 & 23 & 22 & Multiple malformations & 33 & 14 & Yes & 30 \\
\hline 5 & 25 & $20^{+3}$ & Multiple malformations & 30 & 16 & Yes & 28 \\
\hline 6 & 25 & $18^{+5}$ & Multiple malformations & 31 & 15 & Yes & 25 \\
\hline 7 & 28 & $19^{+3}$ & Multiple malformations & 31 & 16 & Yes & 26 \\
\hline 8 & 30 & $21^{+1}$ & Multiple malformations & 35 & 18 & Yes & 28 \\
\hline 9 & 31 & $20^{+2}$ & Multiple malformations & 32 & 16 & Yes & 30 \\
\hline
\end{tabular}

${ }^{\text {a }}$ Superscripted numbers refer to the number of days additional to the specified week.

A

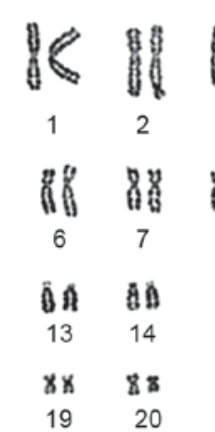

B

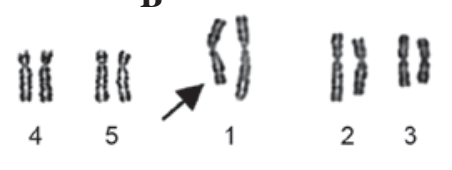

88

\begin{tabular}{|c|c|c|c|c|c|}
\hline ถ & $\hat{A B}$ & $\Delta \mathbf{A}$ & & ถื ถิ & $\mathrm{x} \mathbf{x}$ \\
\hline 13 & 14 & 15 & & 16 & 17 \\
\hline & $8 x$ & & $A B$ & $\Delta s$ & 88 \\
\hline 19 & 20 & & 21 & 22 & $x^{2}$ \\
\hline
\end{tabular}

Figure 4. Chromosomal karyotypes of the bladder fluid cells of Case 2. (A) 46, XX; (B) 46, XX, t(1; 5) (q22; q12). Magnification, x1,000.

of amniotic fluid cells is the most commonly used prenatal genetic diagnostic technique in the clinical setting; it is usually performed after 16 weeks of pregnancy and the availability of a sufficient amount of amniotic fluid is a prerequisite for the use of this technique (1). In addition, chorionic villus biopsy and umbilical vein puncture are also commonly used methods in the clinical setting to obtain fetal cells. In general, villus puncture via the abdominal wall is more suitable from week 11 to week 14 of pregnancy; after a gestational age of 14 weeks, villus biopsy can be performed in principle, but the risks would be relatively high $(17,18)$, and cell culture would be increasingly difficult. Moreover, the results of karyotype analysis might exhibit the phenomenon of chimerism $(19,20)$. Therefore, this method has been replaced by amniocentesis and umbilical blood puncture in cases of late pregnancy. As the umbilical vein diameter is only $\sim 2 \mathrm{~mm}$ at week 16 of pregnancy, puncturing may be difficult, and the risks during puncture could be quite high (10). Hence, the prenatal diagnosis of fetuses with oligohydramnios and megabladder in cases of early pregnancy (that is, from 14 to 16 weeks of pregnancy) is challenging because of the difficulties in obtaining fetal cells. The successful establishment and application of FBPL cell culture technology should facilitate the prenatal fetal chromosome examination of patients with a short gestational age, megabladder and oligohydramnios, and has the potential for use as a new prenatal diagnostic method. The simultaneous presence of oligohydramnios and megabladder is an indication that prenatal diagnosis by examination of the FBPL is appropriate.

Based on our experience, several factors should be considered during the puncture process: i) The whole puncture process should be performed under ultrasonographic guidance; ii) when attempting to puncture the central part of the fetal bladder with the needle, and when the liquid is removed from the bladder, the bladder gradually becomes smaller, and therefore, the depth of the puncture needle should be continuously adjusted to avoid accidentally injuring the fetal organs; iii) the operation should be quick, the guidance and puncturing should be completed by the same physician, and the assistant (who pumps the liquid) should cooperate closely and coordinately. Although all invasive prenatal diagnosis involves the use of probes or needles, FBP involves the direct piercing of the fetus with a needle, and hence, the risks are likely to be high. However, in cases of fetal bladder obstruction the small amount of amniotic fluid limits intrauterine fetal movement, and the large amount of fluid occupying the fetal peritoneal cavity can be clearly observed by ultrasonography; these factors facilitate puncture positioning. Furthermore, since an enlarged bladder causes distention of the fetal abdomen, the abdominal wall is thinner, and therefore, more easily penetrated by the puncture needle when accessing the fetal bladder; also, the abdominal vessels are smaller. Following aspiration, the tension 
on the fetal abdominal wall was decreased, and therefore, the puncture site should close quickly, and sustained bleeding from the puncture site is unlikely to occur. Hence, the risk of FBP is considered to be minimal and the surgery is safe. Nonetheless, the indications should be strictly understood, and the procedure should be performed by experienced doctors.

During fetal development, lower urinary tract obstruction may cause the accumulation of fetal kidney-secreted fluid inside the fetal bladder, which may exhibit progressive enlargement and appear as a megabladder. As there is no fetal urine, the main component in the amniotic cavity, oligohydramnios is an inevitable result. Under normal circumstances, amniotic fluid cells originate from the cells exfoliated from the fetal skin surface, respiratory tract, gastrointestinal tract and genitourinary tract, which are derived from the embryonic ectoderm, mesoderm and endoderm. During embryonic development, chromosomal mutation may occur during the development of different germ layers; therefore, inconsistencies may exist between the karyotypes of amniotic fluid cells and umbilical blood cells (21-23). The cells in bladder fluid originate from the urinary system formed by the mesoderm; therefore, their chromosomes should be consistent with those of umbilical blood cells originating from the mesoderm (24). Therefore, when the chromosomes of FBPL exhibit chimerism, there is no need to withdraw fetal blood for further examination.

Cells obtained by FBPL originate from the bladder and the urinary system, and exhibit similar features to transitional epithelial cells or cubic epithelial cells. The successful in vitro culture of transitional epithelial cells has been reported previously $(25,26)$. Following in vitro culture, the cells appear as fibroblast-like cells. The culture process of FBPL cells is similar to that of amniotic fluid cells. As FBPL cells originate from the urinary system, the number of cells is low and, therefore, a longer culture period is necessary. Hence, the operator is required to be patient. In addition, in the cases in the present study, with the exception of case 2, subculturing was performed, and the relative supernatant was also cultured. Karyotypes obtained for analysis in these cases were therefore significantly increased. Hence, it is recommended that cells from the FBPL should be subjected to subculture in order to improve the success rate of prenatal diagnosis.

In conclusion, our clinical experience indicates that FBP and the culture of FBPL cells is feasible, and can be used for karyotype analysis, which overcomes the limitation that the chromosomal karyotype analysis of bladder fluid cell culture has not previously been performed. Therefore, this may serve as a new method of prenatal diagnosis for patients with bladder outlet obstruction as well as oligohydramnios and megabladder in early pregnancy (gestational age 14-16 weeks). Moreover, it has the potential be used as a method of prenatal diagnosis in early pregnancy when it is not possible to obtain amniotic fluid, villus or umbilical blood, and FBP is suggested to be worthy of wide promotion and application.

\section{References}

1. Steele MW and Breg WR Jr: Chromosome analysis of human amniotic-fluid cell. Lancet 1: 383-385, 1966.
2. Simoni G, Brambati B, Danesino C, Rossella F, Terzoli GL, Ferrari $\mathrm{M}$ and Fraccaro M: Efficient direct chromosome analyses and enzyme determinations from chorionic villi samples in the first trimester of pregnancy. Hum Genet 63: 349-357, 1983.

3. Brambati B, Tului L, Camurri L and Guercilena S: Early second trimester (13 to 20 weeks) transabdominal chorionic villus sampling (TA-CVS): A safe and altemative method for both high and low risk populations. Prenat Dign 22: 907-913, 2002.

4. van den Berg C, Van Opstal D, Brandenburg H, Wildschut HI, den Hollander NS, Pijpers L, Jan H, Galjaard R and Los FJ: Accuracy of adnomal karyotypes after the analysis of both short-and long-term culture of chorionic villi. Prenat Diagn 20: 956-969, 2000.

5. Shaffer LG and Tommerup N (eds): ISCN 2005: An International System for Human Cytogentic Nomenclature. Recommendations of the International Standing Committee on Human Cytogenetic Nomenclature. Karger, New York, 2005.

6. Xiao Y, Wei J, Chen Y, Zhang K, Zhou J and Zhang Y: Trisomy 8 is the most frequent cytogenetic abnormality in de novo myelodysplastic syndrome in China. Onkologie 35: 100-106, 2012.

7. Diego-Alvarez D, Rodriguez de Alba M, Cardero-Merlo R, Diaz-Recasens J, Ayuso C, Ramos C and Lorda-Sanchez I: MLPA as a screening method of aneuploidy and unbalanced chromosomal rearrangements in spontaneous miscarriages. Prenat Diagn 27: 765-771, 2007.

8. Morris RK, Malin GL, Khan KS and Kilby MD: Antenatal ultrasound to predict postnatal renal function in congenital lower urinary tract obstruction: Systematic review of test accuracy. BJOG 116: 1290-1299, 2009.

9. Wu S and Johnson MP: Fetal lower urinary tract obstruction. Clin Perinatol 36: 377-390, 2009.

10. Liao C, Pan M, Li DZ, Zhong YF, Wei JX, Yi CX, Li J and Zhong HZ: Studies on safety of cordocentesis guided by transabdominal ultrasound for prenatal diagnosis. Zhonghua Fu Chan Ke Za Zhi 39: 813-815, 2004 (In Chinese).

11. Lu H, Zhou L, Zhou Y and Yu M: Study on the relationship between fetal umbilical vein width and gestational age. Zhong Hua Wei Chan Yi Xue Za Zhi 11: 51-52, 2008 (In Chinese).

12. Yan Y, Yang X and Ren L (eds): Prenatal ultrasound diagnosis. People's Medical Publishing House, Beijing, pp123-124, 2003.

13. Brun JL, Mangione R, Gangbo F, Guyon F, Taine L, Roux D, Maugey-Laulom B, Horovitz J and Saura R: Feasibility, accuracy and safety of chorionic villus sampling: Areport of 10741 cases. Prenat Diagn 23: 295-301, 2003.

14. Camoana M, Serra A and Neri G. Role of chromosome aberrations in recurrent abortion: A study of 269 balanced translocations. Am J Med Genet 24: 341-356, 1986.

15. No authors listed: ACOG Committee Opinion No. 446: Array comparative genomic hybridization in prenatal diagnosis. Obstet Gynecol 114: 1161-1163, 2009.

16. American College of Obstetricians and Gynecologists Committee on Genetics: Committee Opinion No. 545: Noninvasive prenatal testing for fetal aneuploidy. Obstet Gynecol 120: 1532-1534, 2012.

17. Enzensberger C, Pulvermacher C, Degenhardt J, Kawacki A, Germer U, Gembruch U, Krapp M, Weichert J and Axt-Fliedner R: Fetal loss rate and associated risk factors after amniocentesis, chorionic villus sampling and fetal blood sampling. Ultraschall Med 33: E75-E79, 2012.

18. Valayatham V, Subramaniam R, Juan YM and Chia P: Indications for invasive prenatal diagnostic procedures at a dedicated fetal medicine centre: An 8 year audit 2003-2010. Med J Malaysia 68: 297-300, 2013.

19. Liao J, Sathanoori M, Yatsenko SA, Hu J, Kochmar SJ, Hoffner L, Hogge WA and Surti U: Prenatal detection of del(10)(q11.2) mosaicism in chorionic villus specimens likely caused by a common chromosomal fragile site FRA10G is associated with a normal phenotype. Prenat Diagn 32: 1166-1169, 2012.

20. Sundberg K, Lundsteen C and Philip J: Comparison of cell cultures, chromosome quality and karyotypes obtained after chorionic villus sampling and early amniocentesis with filter technique. Prenat Diagn 19: 12-16, 1999.

21. Hsu LYF: Prenatal diagnosis of chromosomal abnormalities through amniocentesis. In: Genetic Disorders and the Fetus: Diagnosis, Prevention, and Treatment. Milunsky A. 4th edition. Johns Hopkins University Press, Baltimore, p179, 1998. 
22. Brambati B, Macintosh MC, Teisner B, Maguiness S Shrimanker K, Lanzani A, Bonacchi I, Tului L, Chard T and Grudzinskas JG: Low maternal serum levels of pregnancy associated plasma protein A (PAPP-A) in the first trimester in association with abnormal fetal karyotype. Br J Obstet Gynaecol 100: 324-326, 1993.

23. Morales C, Cuatrecasas E, Mademont-Soler I, Clusellas N, Peruga E, Català V, Garrido C, Milà M, Soler A and Sánchez A: Non-mosaic trisomy 20 of paternal origin in chorionic villus and amniotic fluid also detected in fetal blood and other tissues. Eur J Med Genet 53: 197-200, 2010.
24. Aterman K: Pronephros and mesonephros - Cohnheim revisited. Pediatr Pathol 10: 1021-1032, 1990.

25. Kirk D, Kagawa S, Vener G, Narayan KS, Ohnuki Y and Jones LW: Selection growth of normal adult human urothelial cells in serum-free medium. In Vitro Cell Dev Biol 21: 165-171, 1985.

26. Cilento BG, Freeman MR, Schneck FX, Retik AB and Atala A: Phenotypic and cytogenetic characterization of human bladder urothelia expanded in vitro. J Urol 152: 665-670, 1994. 